\title{
CFTR allelic heterogeneity in Brazil: historical and geographical perspectives and implications for screening and counseling for cystic fibrosis in this country
}

\author{
Fabio R Faucz ${ }^{1,2}$, Denise AS Souza ${ }^{1}$, Marcia Olandoski ${ }^{1}$ and Salmo Raskin ${ }^{1}$
}

The goal of the present study was to provide a complete and updated spectrum of cystic fibrosis (CF) transmembrane conductance regulator (CFTR) gene mutations in the Brazilian population combining all available in silico data for patients with CF in Brazil, including founder background and migration flow that consisted of the actual genetic pool of the Brazilian population. Information sources in international databases (PUBMED and SCIELO) were searched. The Brazilian population shows a wide variation in the frequency of CFTR mutations in states Rio Grande do Sul (RS), Santa Catarina (SC), Paraná (PR), São Paulo (SP), Rio de Janeiro (RJ), Minas Gerais (MG), Pará (PA) and Bahia (BA); this variation includes the most common mutation p.F508del. Apparently, this frequency variation is because of the different ethnic compositions. States such as SC and PR have a greater European admixture with almost $90 \%$ of CF alleles identified. In other states, such as BA, higher frequency of alleles that are common among African populations is seen. Overall, the CFTR mutational spectrum indicates the presence of European, African and Amerindian ethnic groups in the contemporary Brazilian CF patients. Here, we present an analysis of the CFTR allelic heterogeneity and discuss the origin of its genetic composition, in an attempt to provide improved perspective for the $\mathrm{CF}$ population screening in Brazil and genetic counseling.

Journal of Human Genetics (2010) 55, 71-76; doi:10.1038/jhg.2009.123; published online 27 November 2009

Keywords: Brazilian CF population; CFTR gene; cystic fibrosis; migration history; mutational spectrum; neonatal screening; population structure

\section{INTRODUCTION}

Cystic fibrosis (CF) is an autosomal recessive disorder caused by deficient chloride transport across the apical membrane of epithelial cells. It is the most common lethal genetic disorder among the population of European origin, with an incidence of about 1 in 2500 live births and a carrier frequency of about 1 in $25 .^{1}$ In 1989 , the gene responsible for $\mathrm{CF}$, referred to as $\mathrm{CF}$ transmembrane conductance regulator (CFTR), was identified. The most common CFTR mutation is a 3-bp deletion causing the loss of phenylalanine residue at position 508 (p.F508del) in exon $10^{2-4}$

More than $95 \%$ of CF mutations have been characterized in several genetically homogeneous populations: $100 \%$ in Hutterites, ${ }^{5} 98.5 \%$ in Belgians, ${ }^{6} 98 \%$ in a French population of Celtic origin ${ }^{7}$ and $97 \%$ in Jewish Ashkenazi. ${ }^{8}$ In heterogeneous populations, the number of different mutations is very large. ${ }^{9-12}$ A worldwide survey found that 28493 of the 43077 studied CF chromosomes (66\%) carried the p.F508del mutation. ${ }^{13}$ The frequency of the p.F508del mutation differs between populations, ranging from 26\% in Algeria and Venezuela to $47 \%$ in one Brazilian study and $87 \%$ in Denmark; other mutations also vary widely depending on the ethnic composition of the studied groups. ${ }^{14-17}$

Because geographic differences in the frequency of CFTR mutations affect the false-negative rates that arise when CFTR mutation analysis is used for diagnosis and carrier testing, such data should be made available for each different region and ethnic group of a specific country. We previously reported mutation heterogeneity in Brazilian CF patients by direct analysis of the p.F508del mutation and other common sequence alterations (p.G542X, p.N1303 K, p.G551D and p.R553X). Our data showed that these five mutations represent only $56 \%$ of CF alleles in Brazil and that their frequencies vary from state to state. ${ }^{16,18,19}$ In this study, we provide the updated data for the entire spectrum of CFTR mutations in the Brazilian population and discuss the origin of its genetic composition in an attempt to provide an improved perspective for the CF population screening in Brazil and for genetic counseling.

${ }^{1}$ Laboratory of Molecular Genetics, Center for Health and Biological Sciences (CCBS), Pontifícia Universidade Católica do Paraná (PUCPR), Curitiba, Paraná, Brazil and ${ }^{2}$ Section on Endocrinology and Genetics, Program in Developmental Endocrinology \& Genetics, Eunice Kennedy Shriver, National Institute of Child Health \& Human Development, National Institutes of Health, Bethesda, MD, USA

Correspondence: Professor FR Faucz, Center for Health and Biological Sciences (CCBS), Pontificia Universidade Catolica do Parana (PUCPR), Rua Imaculada Conceicao, 1155, Prado Velho, Curitiba, Paraná 80215-901, Brazil.

E-mail: fabio.faucz@pucpr.br

Received 3 August 2009; revised 18 October 2009; accepted 19 October 2009; published online 27 November 2009 


\section{MATERIALS AND METHODS}

Data collection

All data were collected after in silico searches were completed in the available databases (PUBMED and SCIELO).

\section{Statistical analysis}

The study results were expressed as a percentage of the total; homogeneity was tested and distributions were analyzed by the $\chi^{2}$-test; and significance was set at a $P$-value of 0.05 . Occasionally, mutations were grouped for analysis. The STATISTICA v8.0 software package (StatSoft South America, São Paulo, SP, Brazil, STATISTICA AXA, Serial Number: AXA809E101819FA-E) was used for all statistical analyses.

\section{RESULTS AND DISCUSSION}

The Brazilian population is one of the most heterogeneous in the world, with a tri-hybrid composition (native Indians, Africans and European descendants) and a high rate of admixture. A consequence of this ethnic mixture is the extensive molecular heterogeneity of CFTR gene alleles in the Brazilian population. We previously studied the p.F508del and other four mutations (p.G542X, p.N1303 K, p.G551D and p.R553X) that are common worldwide in the Brazilian population. These five mutations represented only $56 \%$ of CFTR alleles in Brazil, with their frequencies varying from state to state. ${ }^{16,18,19}$ Apparently, the high heterogeneity of Brazilian population was because of different migratory waves and a large number of different sub-populations. Brazil was conquered by Portugal in 1500; during the 1530s, African slaves were brought to Brazil from north of the Guinea Gulf and Sudan. Additional African populations arrived in Brazil in the $1820 s ;{ }^{20}$ more than four million Africans were brought to Brazil from the 16th to the 19th century. After the abolition of the British and the United States slave trades in 1808, only Cuba and Brazil remained as the major conductors of this activity, and it was Brazil which took more than two-thirds of the 2.9 million Africans who arrived to America after $1800 .^{20}$

African populations were concentrated in specific Brazilian states, such as Minas Gerais (MG). Of the 800000 slaves who obtained freedom by 1888,230000 were from MG. ${ }^{21}$ Accordingly, in MG, there is a high proportion of European/African descendants (44\%) as compared with the state of Paraná (PR) (25.5\%); the population of MG is made up of $45.7 \%$ Brazilians of European origin and $9.7 \%$ of African Brazilians. ${ }^{22}$

Another important migration to Brazil was that of people of European descent, which started in 1802 and decreased dramatically after 1950. From 1875 to 1950, about 5 million Europeans immigrated to Brazil, settling mainly in the Southern states. A total of $80 \%$ of the immigrants came from Portugal, Italy, Spain and Germany. Although this European group was ethnically heterogeneous with a widespread admixture, European descendants are relatively homogeneous, and today, they are found primarily in the South, such as in states of PR and Santa Catarina (SC). ${ }^{21,23}$ SC has the lowest admixture rate in Brazil (5.3\%), with $86.6 \%$ of its current population being of European origin and only $3.6 \%$ comprised of African Brazilians. In PR, 70.3\% of the population is of European origin, whereas 3\% consists of African Brazilians. $^{22}$ Nowadays, Brazilians with a European origin constitute $49.4 \%$ of total population, mixed-race $42.3 \%$, African Brazilians $7.4 \%$, Asians and Amerindians $0.8 \% .^{22}$

The five main Brazilian regions (north, northeast, southeast, south and center-west) (Figure 1) differ in ethnic background and Amerindian contribution. The Amerindian populations underwent a drastic demographic decline because of conflicts with the European colonizers and diseases. ${ }^{21,24,25}$ Today, there are around 326000 Amerindians in
Brazil, located mainly in the northern and western border regions as well as in the upper Amazon basin. Although these groups constitute less than $1 \%$ of the total population, ${ }^{22,26}$ present-day Brazilians still carry alleles from the early colonization phase, as showed by mitochondrial DNA data, indicating that Indian matrilineal contribution to the total present-day Brazilian population with European origin gene pool may be as high as 33\%, varying from $54 \%$ in the northern region to $22 \%$ in the south. ${ }^{27}$ Studies of nuclear markers have shown that the overall (matrilineal and patrilineal) Amerindian contribution is lower, varying from $41 \%$ in the northern ${ }^{28}$ to $7-11 \%$ in the southern regions. ${ }^{29}$ Guarani and Kaingang are currently two of the most populous Amerindian groups in Brazil (41000 and 22000, respectively) and also the major Southern Brazilian Indian populations. They differ in multiple aspects of their cultures, and this correlates with the distinctiveness of their gene pools. ${ }^{30-33}$

The p.F508del common CF mutation shows great variation in frequency among the Brazilian states. The states PR, SC, Rio Grande do Sul (RS), São Paulo (SP) and MG have frequencies between 45.5 and $50 \% ; 11,19,34,35$ Rio de Janeiro (RJ) and Pará (PA) have frequencies of $28.42 \%{ }^{36}$ and $22.73 \%,{ }^{36}$ respectively (Table 1 ). In RJ, the population composition is mainly of African origin (52\%), followed by European origin (40\%) and Amerindians (8\%), ${ }^{37}$ which explains the lower p.F508del frequency. In MG, Raskin et al. ${ }^{11}$ found p.F508del mutation in $47.4 \%$ of 310 chromosomes from Euro-Brazilian patients and in only $10.5 \%$ of 76 chromosomes from African Brazilian patients; corroborating studies suggest that p.F508del mutation was introduced in the European population after the divergence of continental groups. ${ }^{38-40}$ In the case of $\mathrm{MG}$, assuming an admixture rate of about $50 \%,{ }^{21}$ the frequency of $10.52 \%$ in African Brazilian patients could be explained by its mixing with Euro-Brazilians. In PA, the proportion is reverse of that of RJ: European origin 47\%, Amerindians $41 \%$ and African origin $12 \%,{ }^{28}$ suggesting that the lower mutation frequency maybe a result of the mixing of European immigrants with the original populations of the Amazon.$^{41}$ The state with the lowest frequency (only 8.68\%) is Bahia (BA), the population of which descended mainly from Africans and Portuguese. ${ }^{42}$ In this state, only this CF mutation has been studied-its low prevalence may be because of the mixing of African Brazilians with European descendants, mainly Portuguese. The other CF mutations that affect the patients in BA are unknown and genetic studies are required to characterize the genetic basis of $\mathrm{CF}$ in this region, considering the high rate of miscegenation, and strong African and Portuguese component.

Linkage analysis has proven to be useful in identifying mutation loci or mutation carriers when the known common mutations were not detected. This is the case of the XV2C and KM19 (XK) haplotype (see Table 2). More than 650 different CF mutations have been identified and correlated with haplotypes determined by restriction fragment length polymorphisms. ${ }^{43-45}$ In a study of patients from five Brazilian states (RS, SC, PR, SP and MG), Raskin et al. ${ }^{46}$ found that $88 \%$ of p.F508del alleles and $41 \%$ of non-p.F508del CF alleles were associated with haplotype $B$. This finding supports previous data, suggesting a single origin for the p.F508del mutation and a selective advantage of mutations arising on $X K$ haplotype $B .{ }^{47}$ This group also found a relatively and unexpected high number (12\%) of the p.F508del alleles on the $A$ or $D \mathrm{XK}$ haplotype, suggesting that they might have derived from p.F508del mutations on the common CF haplotype $B$ by a single recombination event. Such an event is likely because of two reasons: (i) the region around $\mathrm{XV} 2 \mathrm{C}$ is considered a recombinational hot spot and, (ii) $\sim 200 \mathrm{~kb}$ separate the XK loci from the CF locus. ${ }^{4,48}$ Raskin et al. ${ }^{46}$ suggested that the high frequency of the p.F508del mutations 


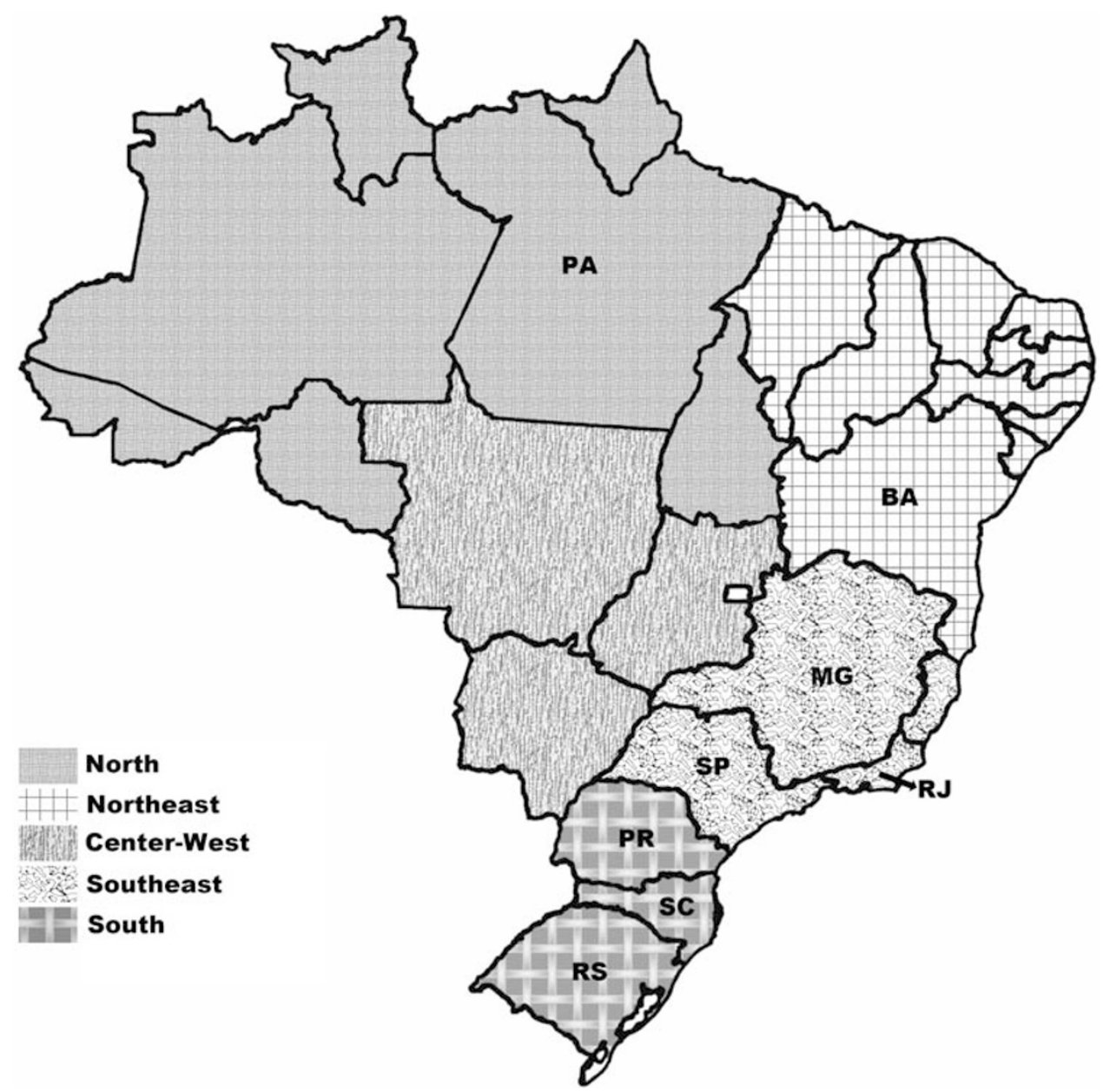

Figure 1 Brazilian states in which the cystic fibrosis transmembrane conductance regulator (CFTR) mutations are analyzed.

Table 1 Frequencies of some mutations in different regions from Brazil

\begin{tabular}{|c|c|c|c|c|c|c|c|c|}
\hline \multirow[b]{2}{*}{ Mutation } & \multicolumn{3}{|c|}{ South } & \multicolumn{3}{|c|}{ Southeast } & \multirow{2}{*}{$\begin{array}{l}\text { North } \\
P A^{37}\end{array}$} & \multirow{2}{*}{$\begin{array}{c}\text { Northeast } \\
B A^{38}\end{array}$} \\
\hline & $P R$ and $S C^{19}$ & $P R$ and $S C^{11}$ & $R S^{35}$ & $S P^{34}$ & $R \mathcal{\beta}^{\beta 6}$ & $M G^{11}$ & & \\
\hline p.G542X & $6.25 \%(7 / 112)$ & $7.65 \%(15 / 196)$ & $3.25 \%(5 / 154)$ & $4.17 \%(8 / 192)$ & $2.10 \%(4 / 190)$ & $7.02 \%(8 / 114)$ & $0.00 \%(0 / 66)$ & nt \\
\hline p.N1303K & $4.46 \%(5 / 112)$ & $5.10 \%(10 / 196)$ & $0.00 \%(0 / 154)$ & $2.08 \%(4 / 192)$ & $\mathrm{nt}$ & $0.00 \%(0 / 114)$ & $\mathrm{nt}$ & $\mathrm{nt}$ \\
\hline p.G85E & $3.57 \%(4 / 112)$ & $2.04 \%(4 / 196)$ & nt & nt & $4.73 \%(9 / 190)$ & $3.51 \%(4 / 114)$ & nt & nt \\
\hline c. $2183 A A>G$ & $2.68 \%(3 / 112)$ & $1.53 \%(3 / 196)$ & nt & nt & $0.00 \%(0 / 190)$ & $0.00 \%(0 / 114)$ & nt & $\mathrm{nt}$ \\
\hline p.W1282X & $2.68 \%(3 / 112)$ & $2.55 \%(5 / 196)$ & $0.65 \%(1 / 154)$ & $0.52 \%(1 / 192)$ & $0.00 \%(0 / 190)$ & $0.88 \%(1 / 114)$ & $\mathrm{nt}$ & $\mathrm{nt}$ \\
\hline p.R553X & $1.78 \%(2 / 112)$ & $1.02 \%(2 / 196)$ & $0.65 \%(1 / 154)$ & $0.52 \%(1 / 192)$ & $0.00 \%(0 / 190)$ & $0.00 \%(0 / 114)$ & $0.00 \%(0 / 66)$ & $\mathrm{nt}$ \\
\hline p.G551D & $0.00 \%(0 / 112)$ & $0.00 \%(0 / 196)$ & $0.00 \%(0 / 154)$ & $1.04 \%(2 / 192)$ & $0.53 \%(1 / 190)$ & $0.00 \%(0 / 114)$ & $4.55 \%(3 / 66)$ & nt \\
\hline
\end{tabular}

Othera $25.89 \%$ (29/112) $24.49 \%$ (48/196) 45.45\% (70/154) 56.25\% (108/192) 61.05\% (116/190) 65.79\% (54/114) 72.73\% (48/66) 91.32\% (263/288)

$$
P=0.9226^{\mathrm{b}} \quad P=0.0007^{\mathrm{c}}
$$

Abbreviations: BA, Bahia state; MG, Minas Gerais state; nt, not tested; PA, Pará state; PR, Paraná state; RJ, Rio de Janeiro state; RS, Rio Grande do Sul state; SC, Santa Catarina state; SP, São Paulo state.

Numbers of chromosomes with the mutation/number of analyzed chromosomes are given in parentheses.

aOther includes uncharacterized mutations, rare variants and not tested mutations.

bHomogeneity test between the PR and SC ${ }^{19}$ and PR and SC ${ }^{11}$ : mutations p.G85E and p.R334W, and the mutations c.2183AA>G, p.W1282X, p.R553X and p.G551D were grouped for the test.

'Homogeneity test between the two previous PR and SC results and RS ${ }^{35}$ : mutations p.N1303 K, p. R1162X, p.W1282X and p.R553X and the mutations p.G85E, c.2183AA>G and 'other' were grouped for the test. 
bearing non- $B$ haplotypes may be because of (i) greater ethnic heterogeneity of European populations that migrated to Brazil (the degree of association is lower in southern European than in northern European populations); (ii) Brazilian internal migration, allowing intensive intra-population exchanges; or (iii) admixture with nonwhite populations of Brazil (manly Africans), who have a different distribution of CF-linked haplotypes. In the states of PR and MG, haplotype $C$ is the most common haplotype on non-p.F508del alleles, whereas in SC, the prevalent haplotype is $A$.

Admixture with nonwhite populations does not seem to have an important role in changing haplotype frequencies in SC and PR. One explanation for the higher mutation frequency on the $A$ and $C$ haplotypes in these states, could be a founder effect brought by the Italian and Portuguese immigrants. This hypothesis is supported by the following facts: (i) haplotypes $A$ and $C$ are overrepresented in nonCF chromosomes from Italy (70\%) and in non-p.F508del CF chromosomes from Portugal (87\%), compared with all the rest of the South European populations; ${ }^{49-51}$ (ii) SC and PR are geographically close; (iii) Raskin et al. ${ }^{18}$ showed that $35 \%$ of SC CF patients are Italian descendants through both sets of grandparents, and at least $40 \%$ are Italian descendants through either maternal or paternal side of the family; (iv) demographic data show that most whites living in the capital of SC (Florianópolis), where most SC subjects and respective parents were born, are Portuguese descendants, and as many as $83 \%$ of individuals born in Florianópolis have both sets of grandparents of Portuguese origin. ${ }^{21,23}$ In the state of MG, $46 \%$ of the non-p.F508del mutations are linked to haplotype $C$. Interestingly, among the five states studied by Raskin et al., ${ }^{18} \mathrm{MG}$ has the least flow of immigrants between 1802 and 1950, and its white population is mainly composed of descendants of Portuguese families who arrived in Brazil after 1500, when Brazil was conquered by Portugal. ${ }^{21,23}$

Table 2 Standard haplotype nomenclature

\begin{tabular}{lcc}
\hline Haplotype & KM19 & XV2C \\
\hline A & 1 & 1 \\
B & 2 & 1 \\
C & 1 & 2 \\
D & 2 & 2 \\
\hline
\end{tabular}

Abbreviations: 1, absence of restriction site for Pstl or Taql; 2, presence of restriction site for Pstl or Taql.
Another nonexclusive explanation would be admixture with the nonwhite population. This is plausible because, of the five states studied, MG has the highest rate of admixture between whites and blacks. ${ }^{21}$ Interestingly, haplotype $C$, which reaches its highest frequency in non-p.F508del CF alleles from the state of MG, is frequent in black Americans: it is the most frequent haplotype in non-CF chromosomes (39\%) and it is overrepresented on CF chromosomes (19\%). ${ }^{52}$

The CFTR mutation spectrum in South Brazil points to the strong influence of the European component, mainly Italian. This can be showed when we compare the occurrence of the eight most frequent mutations in Italy (which consists of $\sim 70 \%$ of all mutations in this country) with those of other populations (Table 3). ${ }^{14,53,54}$ Faucz et al. ${ }^{19}$ found nine mutations with a frequency higher than 1\% (p.F508del: 45.5\%; p.G542X: 6.3\%; p.N1303K: 4.5\%; p.G85E, p.R334W and p.R1162X: total of 3.6\%; c.2183AA $>$ G and p.W1282X: 2.7\%; and p.R553X: $1.8 \%$ ) in CF patients from PR and SC (south of Brazil). These nine mutations represented $74.1 \%$ of the CFTR alleles and 16 others were identified by this group. These 25 mutations accounted for $88.4 \%$ of all CFTR alleles. In Figure 2, we can see the total mutation detection rate in Brazilian states with $\mathrm{CF}$ mutation data.

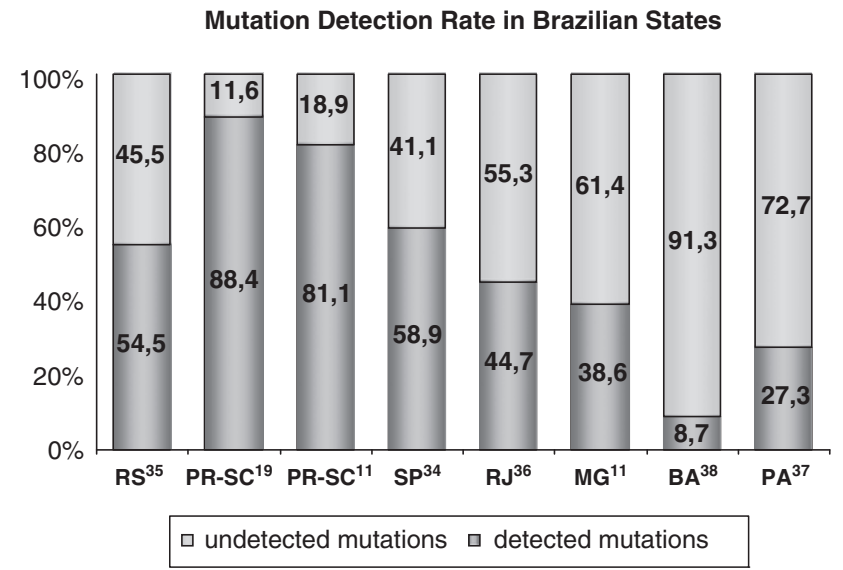

Figure 2 Mutation detection rate in Brazilian states: the states are presented in a south to north order. Rio Grande do Sul (RS), Santa Catarina (SC), Paraná (PR), São Paulo (SP), Rio de Janeiro (RJ), Minas Gerais (MG), Pará (PA) and Bahia (BA).

Table 3 The eight more frequent cystic fibrosis mutations in Italy and the comparison between the frequency of these mutations in south of Brazil with the frequency in Italy, Portugal, Germany and Europe

\begin{tabular}{|c|c|c|c|c|c|}
\hline Mutation & South of Brazil11,19 & Italy $y^{53}$ & Portuga/14 & Germany ${ }^{54}$ & Europe $^{14}$ \\
\hline p.F508del & $46.43 \%(143 / 308)$ & $48.92 \%(745 / 1523)$ & $44.49 \%(202 / 454)$ & $68.39 \%$ (4 199/6 140) & $66.78 \%(18$ 149/27 177) \\
\hline p.G542X & $7.14 \%(22 / 308)$ & $5.91 \%(90 / 1523)$ & $1.32 \%(6 / 454)$ & $1.51 \%(93 / 6140)$ & $2.64 \%(717 / 27$ 177) \\
\hline p.N1303K & $4.87 \%(15 / 308)$ & $5.91 \%(90 / 1523)$ & $0.66 \%(3 / 454)$ & $1.32 \%(81 / 6140)$ & $1.64 \%(446 / 27177)$ \\
\hline p.R1162X & $4.87 \%(15 / 308)$ & $1.58 \%(24 / 1523)$ & $0.22 \%(1 / 454)$ & $0.07 \%(4 / 6140)$ & $0.51 \%(139 / 27177)$ \\
\hline p.W1282X & $2.60 \%(8 / 308)$ & $1.77 \%(27 / 1523)$ & $0.00 \%(0 / 454)$ & $0.24 \%(15 / 6140)$ & $1.00 \%(272 / 27177)$ \\
\hline c. $2183 A A>G$ & $1.95 \%(6 / 308)$ & $2.63 \%(40 / 1523)$ & $0.00 \%(0 / 454)$ & $0.00 \%(0 / 6140)$ & $0.36 \%(99 / 27$ 177) \\
\hline p.R553X & $1.30 \%(4 / 308)$ & $1.38 \%(21 / 1523)$ & $0.00 \%(0 / 454)$ & $1.61 \%(99 / 6140)$ & $0.75 \%(204 / 27177)$ \\
\hline c. $1717-1 \mathrm{G}>\mathrm{A}$ & $0.97 \%(3 / 308)$ & $1.77 \%(27 / 1523)$ & $0.00 \%(0 / 454)$ & $0.50 \%(31 / 6140)$ & $0.83 \%(226 / 27177)$ \\
\hline Others & $29.87 \%(92 / 308)$ & $\begin{array}{c}30.14 \%(459 / 1523) \\
P=0.6401^{a}\end{array}$ & $\begin{array}{c}53.30 \%(242 / 454) \\
P<0.0001^{\mathrm{b}}\end{array}$ & $\begin{array}{c}26.35 \%(1618 / 6140) \\
P<0.0001^{b}\end{array}$ & $\begin{array}{c}25.48 \%(6925 / 27177) \\
P<0.0001^{b}\end{array}$ \\
\hline
\end{tabular}

Numbers of chromosomes with the mutation/number of analyzed chromosomes are given in parentheses.

a Mutations p.R1162X, c.1717-1G > A, p.W1282X, p.R553X and 'others' were grouped for the test.

bMutations p.N1303 K, c.2183AA>G, p.R1162X, c.1717-1G>A, p.W1282X, p.R553X and 'others' were grouped for the test. 
Table 4 Population coverage in 2007 of Neonatal Cystic Fibrosis Screening Program (NCFSP), number of live births, number of positive cases and number of cases monitored by the State

\begin{tabular}{|c|c|c|c|c|c|c|c|c|}
\hline Region & State & $\begin{array}{l}\text { Reference services in } \\
\text { neonatal screening }\end{array}$ & $\begin{array}{l}\text { Stage of neonatal } \\
\text { screening program }\end{array}$ & $\begin{array}{c}\text { Population coverage } \\
\text { NCFSP/state (\%) }\end{array}$ & $\begin{array}{l}\text { Live births, } \\
2007^{a}\end{array}$ & $\begin{array}{l}\text { Positive } \\
\text { cases }\end{array}$ & $\begin{array}{c}\text { Cases expected } \\
\text { (estimated frequency) }\end{array}$ & $\begin{array}{c}\text { Cases monitored } \\
\text { in } 2007\end{array}$ \\
\hline Southeast & MG & UFMG/NUPAD & 3 & 88.57 & $263815^{b}$ & 26 & $12\left(1 / 21277^{60}\right)$ & 96 \\
\hline South & PR & FEPE & 3 & 103.63 & $40414^{c}$ & 7 & $6\left(1 / 6803^{60}\right)$ & Uninformed \\
\hline South & SC & HIJ Gusmão & 3 & 88.73 & 80598 & 16 & $6\left(1 / 12195^{60}\right)$ & 138 \\
\hline Total & 3 & - & - & - & 384827 & 49 & 24 & 234 \\
\hline
\end{tabular}

a Sources: SINASC (information system of live births) from State Secretariats of Health of MG, PR and SC and Ministry of Health, Brazil.

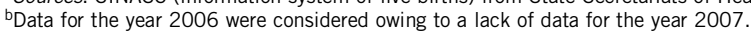

'Live births from January to May 2007.

'The expected cases are calculated on the basis of the percent of cystic fibrosis newborns (of all live births), as described by Raskin et al. ${ }^{60}$

The detection of these mutations that total almost $90 \%$ of all CFTR alleles will greatly improve molecular testing and genetic counseling in PR and SC states. The p.G542X mutation is found more frequently in SP (19.6\%) and MG (13.8\%) than in other states, such as, RJ (2.1\%), RS (4.9\%), SC (6.2\%) and PR (8.7\%). ${ }^{18,36}$ Cabello et al. ${ }^{36}$ found the c. $3120+1 \mathrm{G}>\mathrm{A}$ mutation in $3.7 \%$ of the alleles in RJ; they explained that this higher frequency was most probably the result of the ethnic composition of the RJ population, which generally has a higher proportion of African Brazilians (see Table 1 to compare other mutations found in Brazil). Similar studies must be carried out in other regions and with continental groups of Brazil to define the genetic spectrum of each sub-population.

Sharp and Rock $^{55}$ showed that screening for CF has a significant impact on lung growth and function, and that early intervention (within the first 2 months of life) may be a critical time to make the diagnosis and begin therapies for CF. Because the average CF diagnosis occurs in the fourth year of life in Brazil, ${ }^{34}$ nutritional development and pulmonary function of patients are often compromised. Therefore, the benefits of neonatal screening seem to be undeniable in this country. ${ }^{56}$

On 6 June 2001, the Brazilian Ministry of Health issued the Order GM/MS No 822, which widened the coverage of neonatal screening for $100 \%$ of live births in Brazil and implemented the neonatal screening in three phases: Phase I-screening, diagnostic confirmation, monitoring and treatment of congenital hypothyroidism and phenylketonuria; Phase II—screening, diagnostic confirmation, monitoring and treatment of congenital hypothyroidism, phenylketonuria plus sickle cell disease and other hemoglobinopathies; Phase IIIscreening, diagnostic confirmation, monitoring and treatment of congenital hypothyroidism, phenylketonuria, sickle cell disease and other hemoglobinopathies plus CF. Since 2001, a program implemented by the Fundação Ecumênica de Proteção ao Excepcional do Paraná (FEPE-PR) turned CF screening a reality in the state of PR. The immunoreactive trypsinogen (IRT)/IRT test is used in this state; this method measured levels of IRT in dried blood spots ('Guthrie Cards'). This elevation of trypsinogen is due to trypsinogen leakage into plasma resulting from ongoing pancreatic obstruction and back leakage of acinar content. This method can detect most infants with $\mathrm{CF}$, both pancreatic insufficient and sufficient, and two dosages of elevated IRT is needed to carry out the CF diagnosis. ${ }^{55}$ Currently, PR screens for CF using the IRT/IRT protocol, and the analysis of the p.F508del mutation is being carried out only for research purposes. It is apparent that in other states, such as BA, the use of this mutation for the screening of CF may be useful only if a panel of 40 mutations is included in the test. ${ }^{42}$ The advantage of DNA diagnosis compared with the IRT test is that the DNA test being applied to the same Guthrie card blood spot collected for the IRT test decreases the very high number of false positives, thereby reducing the anxiety related to a second sampling. Costs of calling the newborns and recollecting and reshipping the samples to a reference center are avoided.

After almost 3 years, in PR, the Neonatal Cystic Fibrosis Screening Program (NCFSP) diagnosed a significant percentage of children from the total number of screened subjects (Table 4 ), and the number of diagnosed patients has doubled every year. ${ }^{56} \mathrm{MG}$ and SC are additional states that offer neonatal screening for CF (Phase III of NCFSP); the mean age at diagnosis was 51.4 days and 64 days, respectively, using the IRT/IRT protocol; ${ }^{57,58}$ in SP, in a pilot study for implementation of CF screening, the mean age at diagnosis was 69 days. ${ }^{59}$ These are states that have a population coverage higher than $80 \%$ and have diagnosed the cases expected in the region, according to the expected frequency of CF in that State (Table 4).

We conclude that the discovery of CFTR allelic heterogeneity is important for genetic counseling and for CF screening in the Brazilian population. Regional differences in continental ethnic composition influence both cost-benefit analyses and risk assessments; thus, uniform policies regarding population screening of CF may not be appropriate in a country such as Brazil. To improve the detection of CF mutations in this heterogeneous population, a specific pan-continental mutation panel is needed ${ }^{61,62}$ Further comprehensive CFTR analysis of Brazilian CF patients will provide a powerful tool to identify CF alleles derived from a population in which the disease is supposed to be rare. Because almost $90 \%$ of the CFTR mutations are now identified in the Southern Brazilian population living in the states of $\mathrm{PR}$ and $\mathrm{SC},{ }^{19}$ a carrier screening would be technically possible.

\section{ACKNOWLEDGEMENTS}

We thank Dr Constantine A Stratakis (NICHD, NIH, Bethesda, MD, USA) for critical review of the manuscript and useful suggestions.

1 Boat, T., Welsh, M. \& Beaudet, A. Cystic fibrosis In The Metabolic Basis Of Inherited Disease 6th edn (eds Scriver, C.R., Beaudet, A.L., Sly, W.S. \& Valle, D) 2649-2680 (McGraw-Hill: New York, 1989).

2 Riordan, J. R., Rommens, J. M., Kerem, B., Alon, N., Rozmahel, R., Grzelczak, Z. et al. Identification of the cystic fibrosis gene: cloning and characterization of complementary DNA. Science 245, 1066-1073 (1989).

3 Rommens, J. M., Iannuzzi, M. C., Kerem, B., Drumm, M. L., Melmer, G., Dean, M. et al. Identification of the cystic fibrosis gene: chromosome walking and jumping. Science 245, 1059-1065 (1989).

4 Kerem, B., Rommens, J. M., Buchanan, J. A., Markiewicz, D., Cox, T. K., Chakravarti, A. et al. Identification of the cystic fibrosis gene: genetic analysis. Science 245, 1073-1080 (1989).

5 Zielenski, J., Fujiwara, T. M., Markiewicz, D., Paradis, A. J., Anacleto, A. I., Richards, B. et al. Identification of the M1101 K mutation in the cystic fibrosis transmembrane conductance regulator (CFTR) gene and complete detection of cystic fibrosis mutations in the Hutterite population. Am. J. Hum. Genet. 52, 609-615 (1993). 
6 Cuppens, H., Marynen, P., De Boeck, C. \& Cassiman, J. J. Detection of 98 5\% of the mutations in 200 Belgian cystic fibrosis alleles by reverse dot-blot and sequencing of the complete coding region and exon/intron junctions of the CFTR gene. Genomics $\mathbf{1 8}$, 693-697 (1993).

7 Ferec, C., Audrezet, M. P., Mercier, B., Guillermit, H., Moullier, P., Quere, I. et al. Detection of over $98 \%$ cystic fibrosis mutations in a Celtic population. Nat. Genet. 1, 188-191 (1992).

8 Abeliovich, D., Lavon, I. P., Lerer, I., Cohen, T., Springer, C., Avital, A. et al. Screening for five mutations detects $97 \%$ of cystic fibrosis (CF) chromosomes and predicts a carrier frequency of 1:29 in the Jewish Ashkenazi population. Am. J. Hum. Genet. 51, 951-956 (1992).

9 Casals, T., Ramos, M. D., Gimenez, J., Larriba, S., Nunes, V. \& Estivill, X. High heterogeneity for cystic fibrosis in Spanish families: 75 mutations account for $90 \%$ of chromosomes. Hum. Genet. 101, 365-370 (1997).

10 Claustres, M., Guittard, C., Bozon, D., Chevalier, F., Verlingue, C., Ferec, C. et al. Spectrum of CFTR mutations in cystic fibrosis and in congenital absence of the vas deferens in France. Hum. Mutat. 16, 143-156 (2000).

11 Raskin, S., Pereira, L., Reis, F., Rosario, N. A., Ludwig, N., Valentim, L. et al. High allelic heterogeneity between Afro-Brazilians and Euro-Brazilians impacts cystic fibrosis genetic testing. Genet. Test. 7, 213-218 (2003).

12 des Georges, M., Guittard, C., Altieri, J. P., Templin, C., Sarles, J., Sarda, P. et al. High heterogeneity of CFTR mutations and unexpected low incidence of cystic fibrosis in the Mediterranean France. J. Cyst. Fibros. 3, 265-272 (2004).

13 Tsui, L. C. Population analysis of the major mutation in cystic fibrosis. Hum. Genet. 85, 391-392 (1990).

14 Estivill, X., Bancells, C. \& Ramos, C. Geographic distribution and regional origin of 272 cystic fibrosis mutations in European populations The Biomed CF Mutation Analysis Consortium. Hum. Mutat. 10, 135-154 (1997).

15 Morales-Machin, A., Borjas-Fajardo, L., Pineda, L., Gonzalez, S., Delgado, W., Zabala, W. et al. [Frequency of delta F508 mutation in Venezuelan patients with cystic fibrosis]. Invest. Clin. 45, 121-130 (2004).

16 Raskin, S., Phillips IIIrd, J. A., Krishnamani, M. R., Vnencak-Jones, C., Parker, R. A., Rozov, T. et al. DNA analysis of cystic fibrosis in Brazil by direct PCR amplification from Guthrie cards.. Am. J. Med. Genet. 46, 665-669 (1993).

17 CFMDB. Cystic Fibrosis Mutation Database. http://www3.genet.sickkids.on.ca/cftr/last accessed-18 June (2009).

18 Raskin, S., Phillips, J. A., Kaplan, G., McClure, M., Vnencak-Jones, C., Rozov, T. et al. Geographic heterogeneity of 4 common worldwide cystic fibrosis non-DF508 mutations in Brazil. Hum. Biol. 71, 111-121 (1999).

19 Faucz, F. R., Gimenez, J., Ramos, M. D., Pereira-Ferrari, L., Estivill, X., Raskin, S. et al. Cystic fibrosis in a southern Brazilian population: characteristics of $90 \%$ of the alleles. Clin. Genet. 72, 218-223 (2007).

20 Bortolini, M. C. \& Salzano, F. M. Âs haplotype diversity in Afro-Americans, Africans, and Euro-Asiatics: an attempt at a synthesis. J. Braz Assoc. Adv. Sci. 51, 175-180 (1999).

21 Salzano, F. \& Freire-Maia, N. Populaçõesbrasileiras:Aspectosdemográficos, Genéticoseantropológicos. (Companhia Editora Nacional: São Paulo, 1967).

22 IBGE. (Instituto Brasileiro de Geografia e Estatística) Brazilian census. Sintese de Indicadores Sociais: Uma analise das condicoes de vida da populacao brasileira (Rio de Janeiro: IBGE, 2008).

23 Salzano, F. \& Pena, S. D. Ethics and medical genetics in Brazil In Ethics and Human Genetics: A Cross-Cultural Perspective (eds Wertz, D. \& Fletcher, J.C.) 100-118 (Verlag, Heidelberg: Springer, 1987).

24 Monteiro, J. M. Negros da Terra, Índios e Bandeirantes Nas Origens de São Paulo. (Companhia das Letras: São Paulo, 1994).

25 Ribeiro, D. O. Povo Brasileiro: A Formação e o Sentido do Brasil. (Companhia das Letras: São Paulo, 1995).

26 Salzano, F. M. \& Callegari-Jacques, S. M South American Indians. A Case Study In Evolution (Clarendon Press: Oxford, 1988).

27 Alves-Silva, J., da Silva Santos, M., Guimarães, P. E., Ferreira, A. C., Bandelt, H. J., Pena, S. D. et al. The ancestry of Brazilian mtDNA lineages. Am. J. Hum. Genet. 67, 444-461 (2000).

28 Santos, S. \& Guerreiro, J. F. The indigenous contribution to the formation of the population of the Brazilian Amazon Region. Braz. J. Genet. 18, 311-315 (1995).

29 Dornelles, C. L., Callegari-Jackes, S. M., Robinson, W. M., Weimer, T. A., Franco, M. H. L. P., Hickmann, A. C. et al. Genetics, surnames, grandparent's nationalities and ethnic admixture in Southern Brazil: do the patterns of variation coincide? Genet. Mol. Bio. 22, 151-161 (1999).

30 Petzl-Erler, M. L., Luz, R. \& Sotomaior, V. S. The HLA polymorphism of two distinctive South-American Indian tribes: the Kaingang and the Guarani. Tissue Antigens 41, 227-237 (1993).

31 Petzl-Erler, M. L. \& McDevitt, H. O. Molecular analysis of the HLA-DRB genes in two tribes of Brazilian Indians. Hum. Immunol. 41, 180-184 (1994).

32 Salzano, F. M., Callegari-Jacques, S. M., Weimer, T. A., Franco, M. H. L. P., Hutz, M. H \& Petzl-Erler, M. L. Electrophoretic protein polymorphisms in Kaingang and Guarani Indians of Southern Brazil. Am. J. Hum. Biol. 9, 505 (1997)

33 Faucz, F. R., Probst, C. M. \& Petzl-Erler, M. L. Polymorphism of LMP2, TAP1, LMP7 and TAP2 in Brazilian Amerindians and Caucasoids: implications for the evolution of allelic and haplotypic diversity.. Eur. J. Immunogenet. 27, 5-16 (2000).

34 Alvarez, A. E., Ribeiro, A. F., Hessel, G., Bertuzzo, C. S. \& Ribeiro, J. D. Cystic fibrosis at a Brazilian center of excellence: clinical and laboratory characteristics of 104 patients and their association with genotype and disease severity. J. Pediatr. 80, 371-379 (2004).
35 Streit, C., Burlamaque-Neto, A. C., de Abreu e Silva, F., Giugliani, R. \& Saraiva Pereira, M. L. CFTR gene: molecular analysis in patients from South Brazil. Mol. Genet. Metab. 78, 259-264 (2003).

36 Cabello, G. M., Cabello, P. H., Otsuki, K., Gombarovits, M. E., Llerena Jr, J. C. \& Fernandes, $\mathrm{O}$. Molecular analysis of 23 exons of the CFTR gene in Brazilian patients leads to the finding of rare cystic fibrosis mutations.. Hum. Biol. 77, 125-133 (2005).

37 Lopez-Camelo, J. S., Cabello, P. H. \& Dutra, M. G. A simple model for the estimation of congenital malformation frequency in racially mixed populations. Braz. J. Genet. 19, 659-663 (1996).

38 Morral, N., Llevadot, R., Casals, T, Gasparini, P, Macek, M., Dörk, T. et al. Independent origins of cystic fibrosis mutations R334W, R347P, R1162X and $3849+10 \mathrm{kbC} \rightarrow \mathrm{T}$ provide evidence of mutation recurrence in the CFTR gene. Am. J. Hum. Genet. 55, 890-898 (1994).

39 Macek, M. J., Mackova, A., Hamosh, A., Hilman, B. C., Selden, R. F., Lucotte, G. et al. Identification of common cystic fibrosis mutations in African-Americans with cystic fibrosis increases the detection rate to 75\%. Am. J. Hum. Genet. 60, 1122-1127 (1997).

40 Friedman, K. J., Leigh, M. W., Czarnecki, P. \& Feldman, G. L. Cystic fibrosis transmembrane-conductance regulator mutations among African Americans. Am. J. Hum. Genet. 62, 195-196 (1998).

41 Araujo, F. G., Novaes, F. C., Santos, N. P., Martins, V. C., Souza, S. M., Santos, S. E. et al. Prevalence of deltaF508, G551D, G542X, and R553X mutations among cystic fibrosis patients in the North of Brazil. Braz. J. Med. Biol. Res. 38, 11-15 (2005).

42 Costa, F. M. M., Santana, M. A., Lemos, A. C. M., Galvão-Castro, B. \& Acosta, A. G. Low frequency of the DF508 mutation of the CFTR gene in a highly admixed population in Bahia. Brazil. Hum. Biol. 79, 293-297 (2007).

43 Estivill, X., Farral, M., Scambler, P. J., Bell, G M, Hawley, K M, Lench, N J et al. A candidate for the cystic fibrosis locus isolated by selection for methylation-free islands. Nature 326, 840-845 (1987).

44 Estivill, X., Scambler, P. J., Wainwright, B. J., Hawley, K., Frederick, P., Schwartz, M. et al. Patterns of polymorphisms and linkage disequilibrium for cystic fibrosis. Genomics 1, 257-263 (1987).

45 Cystic Fibrosis Genetic Analysis Consortium (CFGAC). Newsletter 67 (1996).

46 Raskin, S., Phillips, J. A. \& Krishnamani, M. R. S. Regional distribution of cysticfibrosis linked DNA haplotypes in Brazil: multicenter study. Hum. Biol. 69, 75-88 (1997).

47 European Working Group on CF Genetics.. Gradient of distribution in Europe of the major CF mutation and of its associated haplotype. Hum. Genet. 85, 436-446 (1990).

48 Dork, T., Neumann, T., Wulbrand, U., Wulf, B., Kälin, N., Maass, G. et al. Intra- and extragenic marker haplotypes of CFTR mutations in cystic fibrosis families. Hum. Genet. 88, 417-425 (1992).

49 Novelli, G., Gasparini, P., Savola, A., Pignatti, P F., Sangiuolo, F. \& Dallapiccola, B. Polymorphic DNA haplotypes and delta F508 deletion in 212 Italian CF families. Hum. Genet. 85, 420-421 (1990).

50 Ferrari, M., Antonelli, M., Bellini,, F., Borgo, G., Castiglione, O., Curcio, L. et al. Genetic differences in cystic fibrosis patients with and without pancreatic insufficiency: an Italian collaborative study.. Hum. Genet. 84, 435-438 (1990).

51 Duarte, A., Barreto, C., Marques-Pinto, L., Tavares, M C., Amil, J., Pinto, M. et al. Cystic fibrosis in the Portuguese population: haplotype distribution and molecular pathology.. Hum. Genet. 85, 404-405 (1990).

52 Cutting, G. R., Antonarakis, S. E., Buetow, K. M., Kasch, L. M., Rosenstein, B. J. \& Kazazian, H. H. Analysis of DNA polymorphism haplotypes linked to the cystic fibrosis locus in North American Black and Caucasian families supports the existence of multiple mutations of the cystic fibrosis gene. Am. J. Hum. Genet. 44, 307-318 (1989).

53 Bossi, A., Casazza, G., Padoan, R. \& Milani, S. What is the incidence of cystic fibrosis in Italy? Data from the National Registry (1988-2001). Hum. Biol. 76, 455-467 (2004).

54 Wiedemann, B., Steinkamp, G., Sens, B. \& Stern, M. The German cystic fibrosis quality assurance project: clinical features in children and adults. Eur. Respir. J. 17, 11871194 (2001).

55 Sharp, J. K. \& Rock, M. J. Newborn screening for cystic fibrosis. Clin. Rev. Allerg. Immunol. 35, 107-115 (2008).

56 Santos, G. P., Domingos, M. T., Wittig, E. O., Riedi, C. A. \& Rosário, N. A. Neonatal cystic fibrosis screening program in the state of Parana: evaluation 30 months after implementation. J. Pediatr. 81, 240-244 (2005).

57 Honorio, L. F. O., Ludwig Neto, N., Barbosa, E., Perin, N., Gastaldi, L. A., Ferreira, J. E. et al. Avaliação da triagem neonatal para fibrose cística no Estado de Santa Catarina. J. Bras. Pneumol. 32, 1-16 (2006).

58 Reis, F., Melo, S. O. \& Vergara, A. A. Programa de triagem neonatal para fibrose cística de Minas Gerais (PETN-FIBROSE CÍSTICA): aspectos clínicos e laboratoriais. J. Bras. Pneumol. 32, S1 (2006).

59 Rodrigues, R., Gabetta, C. S., Pedro, K. P., Valdetaro, F., Fernandes, M. I., Magalhães, P. K. et al. Cystic fibrosis and neonatal screening. Cad. Saude Publica. 24, 475-484 (2008).

60 Raskin, S., Pereira-Ferrari, L., Reis, F. C., Abreu, F., Marostica, P., Rozov, T. et al. Incidence of cystic fibrosis in five different states of Brazil as determined by screening of p.F508del mutation at the CFTR gene in newborns and patients. J. Cyst. Fibros 7, 15-22 (2008).

61 Heim, R. A., Sugarman, E. A. \& Allitto, B. A. Improved detection of cystic fibrosis mutations in the heterogeneous US population using an expanded, pan-ethnic mutation panel. Genet. Med. 3, 168-176 (2001).

62 Bobadilla, J. L., Macek Jr, M., Fine, J. P. \& Farrell, P. M. Cystic fibrosis: a worldwide analysis of CFTR mutations-correlation with incidence data and application to screening. Hum. Mutat. 19, 575-606 (2002). 